\title{
Introduction: Economics Meets Sociology in Strategic Management
}

\section{Citation}

Dobbin, Frank, and Joel A. C. Baum. 2000. "Introduction: Economics Meets Sociology in Strategic Management." In Advances in Strategic Management, Vol. 17, Economics Meets Sociology in Strategic Management, ed. Brian Silverman, 1-26. Bingley, UK: Emerald.

\section{Published Version}

doi:10.1016/S0742-3322(00)17001-9

\section{Permanent link}

http://nrs.harvard.edu/urn-3:HUL.InstRepos:14117737

\section{Terms of Use}

This article was downloaded from Harvard University's DASH repository, and is made available under the terms and conditions applicable to Other Posted Material, as set forth at http:// nrs.harvard.edu/urn-3:HUL.InstRepos:dash.current.terms-of-use\#LAA

\section{Share Your Story}

The Harvard community has made this article openly available.

Please share how this access benefits you. Submit a story.

Accessibility 


\section{Economics meets Sociology in Strategic Management Advances in Strategic Management, Volume 17}

\section{Introduction: Economics Meets Sociology in Strategic Management}

Frank Dobbin and Joel A.C. Baum

\section{Two Perspectives on the Firm}

Why do firms do what they do? Why does one cut prices while its neighbor buys out competitors? Why does one diversify into new industries while its neighbor spins off subsidiaries to focus on its core competence? Why do some strategies rise while others fall? These are central concerns of both strategic management theorists and economic sociologists. We bring the two fields together to discuss their approaches to these questions with the goal of encouraging dialogue and cross-fertilization. Each field provides a snapshot of firm behavior from a particular vantage point. When these snapshots are integrated, something closer to a three-dimensional view of the firm appears.

Both economic sociology and strategic management draw on diverse ideas. Economic sociologists draw on Max Weber's ideas about institutions, Émile Durkheim's ideas about social milieu and identity, and Karl Marx's ideas about power. Strategic management theorists draw not merely on different paradigms, but on different disciplines: economics, psychology, and sociology. Despite the diversity within the two fields, there are some very fundamental differences between them.

First, they view the firm from different standpoints. In a nutshell, strategists explore efficiency from the perspective of the firm, developing theories of why one strategy is more successful than another, given product, firm, and industry characteristics. Sociologists focus on efficiency from the perspective of the corporate environment, developing theories about the context in which one strategy becomes defined as efficient and diffuses across the corporate landscape.

Second, they begin with very different methodological imperatives. Strategists seek to develop adequate theories of why certain strategies are optimal, or at least efficient, based typically on insights from successful firms. Sociologists seek to explain variance in behavior across large populations of firms and over time, typically using multivariate models that control for diverse potential causes. These differences derive in part from their very different goals - strategic management is oriented to developing concrete prescriptions for corporate leaders from exemplary cases, whereas economic sociology is oriented to explaining trends in corporate behavior post hoc. What makes Ikea work? Why has Apple rebounded so successfully? For strategic theorists, the goal is to explain the success of a strategy, before it has become standard operating procedure -- when firms can still benefit from adopting it. For sociologists, the goal is to explain how context and history contribute to management trends, after those trends have come and, sometimes, gone. In consequence, strategic theorists may see the ideas of sociologists as too little and too late, and sociologists may see the ideas of strategic theorists as premature and based on unrepresentative samples. 
In other words, the most basic method in strategic management is to observe the winners and look for what makes them win. The most basic method in economic sociology is to observe large numbers of firms and look for what explains differences in their behavior, following the comparative analytic strategy outlined by John Stuart Mill and Émile Durkheim.

Third, the two fields start with very different premises. Strategic theorists presume that firm behavior is driven principally by competitive pressures and the quest for efficiency. Analysts tend to give great power to market factors, and relatively little power to historical, political, and social factors. Sociologists also see competitive pressures and the quest for efficiency as important, but they see competition as occurring within a highly structured historical and regulatory context. Competitive pressures may lead firms to alter their strategies, but the new strategies they choose are shaped by public policy, imitation, network position, power, and historical happenstance.

Despite the fact that the two fields share a focus on firm behavior, dialogue between them has been rare. In part, this is due to a disciplinary divide. Economic sociology is for the most part located in sociology departments; whereas strategic management is located firmly in business schools. In part, interaction has been rare because the theoretical and empirical foundations of the two groups remain at a distance. Yet some scholars from each group have begun to build bridges to cross the divide. We hope to fortify those bridges and foster a more active debate and collaboration.

\section{Structure of the Volume}

We reprint four pairs of articles to show that these two fields have a common subject (firm behavior) but very different ways of approaching that subject. In each pair, we match a classic in economic sociology with one in strategic management.

In making the selections, we chose pairs in which each article deals with the same broad phenomenon. How do the two fields explain diversification, or the fact that firm characteristics resist change? In each pairing, readers can make a head-to-head comparison of the two approaches. We wanted the volume to provide a good introduction to each field, so we chose some of the best and most influential articles from each field. Sharon Oster and Harrison White explore how firms develop business strategies, and why their strategies persist. David Teece and Neil Fligstein explain why firms diversify. C.K Pralahad and Richard Bettis and Paul DiMaggio and Walter Powell explore where management models come from. Jay Barney and Arthur Stinchcombe examine the factors that cause firm characteristics to persist.

To illuminate differences in approach, we initiate a dialogue between the authors of these influential articles. We ask each author to reread the pair of articles and write an essay on their points of agreement, on their differences, and on their influence. We ask two outsiders - one from economic sociology and one from strategic management - to comment. Finally, we return to each original author for a final word. The essays are incisive and engaging, focusing on differences in basic assumptions, differences in method, and differences in findings. The outside commentators do a superb job of stepping back and discussing the work from the perspective of 
the field. The end result, as you will see, is a rich and detailed discussion of differences in theory, method, and philosophy, not only in the articles at hand, but in the fields more broadly.

To be sure, some of the contentiousness and rivalry between the fields shows up in the essays and commentaries. Researchers in each field defend their approach vigorously, setting the stage for a lively and entertaining debate. At the same time, the authors recognize the limitations of their own approach and the strengths of the other, and most favor a rapproachment.

We devote the remainder of the introduction to three tasks. First, we illustrate the fundamental differences between the two fields with the case of diversification. Second, we sketch the origins of each field in brief. Third, we introduce each pair of articles, in the process explaining why we chose these particular pairs and how they illuminate the strengths of the two fields.

We close the volume with an epilog, inspired by our watching the dialogue unfold, that explores the sociology-of-science of the two fields. There we discuss the two groups' fundamental epistemologies, and explore paradigm development by way of a cross-citation analysis of economic sociology, organization and management theory, strategic management, and economics (based on papers published by the commentors to this volume).

\section{Two Perspectives on Diversification}

To illustrate our view that strategic management and economic sociology offer complementary explanations, we begin with a comparison of David Teece's article on the multiproduct firm and Neil Fligstein's article on the multidivisional form, both of which are reprinted in this volume. The two articles are concerned with the same broad outcome, although they define that outcome slightly differently. Teece is concerned with the move into multiple product lines; whereas Fligstein is concerned with the adoption of the multi-divisional form which, as Chandler (1962) argues, is typically a consequence of adding product lines.

The question itself - why do firms diversify - is asked in different ways by the two fields. Why is it efficient for some firms to diversify, and for which firms is it efficient? These questions are typical of strategic management theorists. Why do firms jump on the diversification bandwagon, and why does a particular firm jump at a particular time? These questions are typical of economic sociologists.

For strategic management theorists, the problem is to divine an argument based in efficiency. What makes diversification efficient? David Teece's much-cited paper begins with transaction cost theory. Firms with excess capacity make use of their particular knowledge assets to take advantage of market imperfections by moving into new product lines. The theory is elegant, cogent, and compelling. It provides an explanation of the multiproduct firm that builds on neoclassical theory with new ideas from institutional economics. It offers universal predictions, which should be applicable under a wide range of conditions. Teece's use of history is telling. The multiproduct strategy became common during the 1930s, and he links this not to the historical event of the Great Depression, but to the fact that the depression made excess capacity a common problem. 
For economic sociologists, the problem is to explain the social processes behind the rise of a new business practice. What gave rise to the diversification trend? Sociologist Neil Fligstein, in an influential article that we pair with Teece's, emphasizes that change is often stimulated by environmental shocks, and that new strategies often result from two social processes; imitation and power struggles. He looks for exogenous shocks that lead firms to search for new strategies, and for the actors within those firms who promote new approaches. The Celler-Kefauver Act of 1950 was just such a shock, in that it opened horizontal and vertical mergers to federal scrutiny and encouraged firms to spend excess capital on other kinds of acquisitions. Finance managers were the key actors, in that they championed diversification as an efficient use of capital, and in the process expanded their own power within the corporation. Fligstein employs quantitative data from large firms between 1919 and 1979 to test the theory.

Teece develops an explanation of what makes the multiproduct strategy efficient for the firm. Fligstein develops an explanation of why diversification became popular where and when it did. It is possible to view these two perspectives as at odds - one can see Teece as insisting that transaction costs alone explain the multiproduct strategy and Fligstein as explaining that politics and power alone explain the M-form. But it is also possible to view these two perspectives as complementary - one can see Teece as explaining why multiproduct firms are profitable and Fligstein as explaining why diversification happens in historical waves. To view these perspectives as fundamentally incompatible, one has to believe that Teece and Fligstein see their own theories as fully deterministic - as outlining necessary and sufficient conditions for explaining diversification. Neither author takes such a stand, thus we are inclined to see the two perspectives as potentially complementary.

In fact, a study by Gerald Davis, Kristina Diekmann, and Catherine Tinsley (1994), which charts the reversal of the diversification trend during the 1980s, demonstrates, as well as any paper we know of, the utility of combining these two perspectives. Davis and colleagues show that during the 1980s, diversified corporations became the object of bust-up takeovers by corporate raiders; diversified firms sold off unrelated businesses; and large firms stopped diversifying. The result was a dramatic turnaround in the diversification trend. What caused this? On the one (economic) hand, Davis et al. cite the inefficiencies inherent in diversification. Financial orthodoxy dictates that investors, not firms, should diversify. Investors came to see the folly of grouping unrelated businesses under a single management team, and thus assigned lower value to conglomerates than to similar, more focused, firms (Davis et al. 1994, p. 548). On the other (sociological) hand, the legal environment changed the rules of the game and a new strategic model spread among entrepreneurs. Legal incentives to buy unrelated businesses, and disincentives to pursue hostile takeovers, diminished during the Reagan era. And the corporate raider model, in which a lone cowboy wrests control of a corporation from its managers and sells the parts at a profit, diffused across the economy by imitation (as did the poison pill, which, it was hoped, would undermine that model (Davis 1991)).

Davis and colleagues thus construct an argument about why the diversification craze that continued through the 1970s was, in many cases, inefficient. But they also track the sociological process, involving regulatory changes and the rise of a new business model, which caused that inefficient fad to be turned around. They show that competition and efficiency may underlie strategic changes, but that sociological processes play a role in the creation and diffusion of new 
strategies. By combining the perspectives, Davis and colleagues arrive at an explanation that is more satisfactory and complete than either perspective alone would have been. This article, in our view, illuminates the potential for learning and collaboration across the two fields.

Next we introduce the two fields and sketch their origins. Strategic management theory has its roots in economics, although theorists draw liberally from other disciplines. The new economic sociology has strong links to pioneers in sociology; Weber, Durkheim, and Marx.

\section{Foundations of the Two Fields}

\section{Economic Origins of Contemporary Strategic Management}

Mainstream economics--price theory--has traditionally ignored the role of managers and left little scope for strategic choice. The firm in economic theory observes market prices and then makes efficient choices of output quantities. All firms are alike, having access to the same information and technology, and the decisions they make are rational and predictable, driven by cost and demand conditions. The fundamental questions are, what phenomena can be explained by models that assume that human action is rational, and, when no human agent has made an explicit choice, which institutional arrangements can be explained by assuming that they were designed and structured by a rational actor? Little attention is given to why firms might use managerial hierarchies to plan and coordinate; institutional settings and arrangements are abstracted away; and the varied character and capabilities of 'real firms' are not considered.

Strategic management addresses these limitations of price theory by drawing on two fields within economics--industrial organization and microeconomics. Adhering closely to neoclassical economic assumptions about firm homogeneity, Harvard's industrial organization 'structureconduct-performance' (SCP) approach attributes most variation in firm performance to differences across industries (e.g., Bain, 1956; Mason, 1957). Basic industry characteristics (features of the relevant production technology, for example) affect an industry's competitive structure (entry barriers, cost structures, number and size of rivals), which affects the conduct of rivals (pricing behavior, product strategy, advertising, R\&D, capital investment), which in turn affects firms' economic performance (production and allocative efficiency, technological progress, full employment, distributional equity).(1) Harvard industrial organization economics seeks to explain how market processes direct the activities of firms in meeting consumer demand, how market processes break down and result in socially wasteful 'monopoly profits,' and how these processes adjust (or can be adjusted) to improve economic performance.

In the 1960s, the Chicago School of industrial organization (Demsetz, 1973; Stigler, 1968) challenged the Harvard view of entry barriers in industrial organization. Chicago challengers did not view strategies such as collusion to create entry barriers as necessarily anti-competitive. Rather, they saw the principal managerial objective as profit maximization through development of specialized, high-quality resources and capabilities. The role of the manager implied in this view was one of strategic management's points of departure from the Harvard structure-conductperformance (SCP) view. 
Caves and Porter (1977; Porter 1979), attempted to rescue the Harvard SCP view by combining structural and behavioral (strategic) variables, rewriting the SCP causal chain as 'conductstructure-performance' and proposing that "strategic groups" explain firm conduct and performance. Although the SCP approach had little to say about how managers organize and direct a particular firm, Porter's inverted framework could be used to define and explain the strategies available to firms in their search for profits.

The same period also witnessed departures from rational-choice neoclassical microeconomics. Resource-based theory emerged from a dissatisfaction with the ability of the neoclassical theory of the firm--designed for the theory of price determination and resource allocation--to handle real-world management problems outside of the equilibrium context. Resource-based theory emphasizes how heterogeneity in firms' internal characteristics and the resources and capabilities they control generates heterogeneity in their performance. This approach reaches back to the work of Penrose (1959: 31) who provided a new, dynamic conceptualization of the firm -- as "an administrative organization and as a collection of resources" -- designed to explain firm level growth.

Building on the work of Coase (1937) on firm boundaries and internal organization, and Chandler (1962) on the strategic growth, administrative evolution, and economic performance of large firms, Williamson (1975) explored the boundaries of both markets and firms as arrangements for conducting economic activity. Transaction cost theory challenges the microeconomic assumption that actors are fully rational. It suggests that transactions should take place within the regime--firm or market--that best economizes on costs imposed by uncertainty, bounded rationality, information asymmetry, and opportunism.

Although economics was instrumental to the evolution of the strategic groups, resource-based, and transaction cost models, much subsequent development and growth in these areas has taken place within strategic management, which emerged as a separate field in the mid-1970s.

Strategic Groups. The strategic groups approach grew out of ferment in industrial organization economics. One stream begins with the industry as the basic unit of analysis and then disaggregates the industry into component strategic groups (Oster, 1982; Porter, 1980). The second stream takes the firm as the basic unit of analysis and aggregates firms into strategic groups (Hatten \& Schendel, 1977; Rumelt, 1984, 1991). The strategic groups literature has focused on three interrelated questions: How do strategic groups emerge? Does a firm's performance depend on strategic groups? How do firms change strategic groups (Bogner, Mahoney \& Thomas, 1998)? A strategic group is defined as "a set of firms competing within an industry on the basis of similar combinations of scope and resource commitments" (Cool \& Schendel, 1987: 1106). Path-dependent, strategic investments in information and technology acquired to develop factor market imperfections and isolating mechanisms (Lippman \& Rumelt, 1982) are at the heart of strategic group formation. Firms making similar commitments develop similar competitive resources, pursue similar customers and environmental opportunities in similar ways, and form strategic groups. Although strategic groups may result from explicit collusion and the creation of entry barriers by mutual threat - an idea consistent with industrial organization -- they can also arise when firms make similar resource investments.(2) 
Transaction Cost Theory. Transaction cost (TC) theory has been characterized as "the ground where economic thinking, strategy, and organization theory meet" (Rumelt et al., 1994). Williamson $(1975,1985)$, the chief proponent, contends that economizing is more fundamental than strategizing -- economy is the best strategy (Williamson, 1991). The theory is explicitly comparative, addressing the relative efficiencies of markets and hierarchies and, more recently, hybrid arrangements (Williamson, 1991). In effect, transaction cost theory provides a set of normative rules for strategically choosing among alternative arrangements (Masten, 1993). It has been applied to the structure of vertical supply relations (Masten \& Meehan, 1989), multinational firms (Kogut, 1988), and joint ventures (Pisano, 1990). Of particular significance is the M-form hypothesis, which introduces self-restraints that attenuate managerial discretion (Armour \& Teece, 1978). TC theorists have also focused on explaining the "make or buy" decision - on whether firms integrate particular stages in production (Walker \& Weber, 1984). They have made less headway in explaining the effect of this decision on performance. Of course, "whether a theory of governance choice is a good predictor of actual behavior reveals little about the cost of failing to choose the correct organizational arrangement and may be a poor guide to whether a particular theory offers sound prescriptions for business decisions" (Masten, 1993: 119).

Resource-based Theory. Resource-based (RB) approaches build on work on the theory of the firm begun by Penrose (1959). In early conceptions, the RB view emphasized how variation in firms' access to key factor inputs could lead to variation in firm performance within an industry, and to variation in the attractiveness of a particular industry for a particular firm (Wernerfelt, 1984; Barney, 1991). As it developed, the resource-based view extended its focus to a firm's ability to combine inputs rather than on mere access to them. This 'competence-based' view attempts to explain how knowledge affects organization structure, as well as variation in firm performance (Foss, 1996). RB approaches now include a broad menu including the resourcebased (Barney, 1991; Wernerfelt, 1984), commitment (Ghemawat, 1991), dynamic capabilities (Teece \& Pisano, 1994; Teece, Pisano, \& Schuen, 1997), knowledge-based (Foss, 1996), relation-based (Dyer \& Singh, 1998), and attention-based (Ocasio 1997) approaches. In resourcebased theory, resources--financial, human, intangible, organizational, physical, technological-are the basic unit of analysis. These resources must be built. They are not readily assembled in markets because they represent ways of getting things done that cannot be coordinated by the price system (Teece, 1982). In resource-based theory the persistence of firm profits results from idiosyncratic combinations of rent-generating resources--unique historical conditions, locations, firm-specific commitments, difficulties in selling information and opportunism (Ghemawat, 1991; Teece, 1982) -- and property rights--which other firms can imitate only imperfectly (Lippman \& Rumelt, 1982). Resource-based theory focuses on non-monopoly rents derived from source other than collusion and government cooptation -- for example, Ricardian rents (Ricardo, 1917) based on the possession of scarce and valuable resources (Peteraf, 1993), or Schumpeterian rents (Schumpeter, 1934), based on successful entrepreneurial development of new combinations of resources that are a source of rents for a significant period of time. In the Schumpeterian view, even if a resource does not yield rents in the long run, as long as the process of adjustment to the zero-rent state is slow, substantial quasi-rents may still be earned in the middle-run (Mahoney \& Pandian, 1992; Mosakowski, 1993; see also the BarneyStinchcombe essays, this volume). Resource-based theory is concerned with both limits to the ex post equilibration of rents and quasi-rents derived from resources that are sustained for a 
significant, but not infinite, period. Thus, it is usefully informed by both equilibrium (Lippman \& Rumelt, 1982) and disequilibrium views (Teece et al. 1997).

Is That All There Is? Although we highlight strategic management approaches with 'economic' origins (reflected in--indeed pioneered by--the Barney, Oster, and Teece articles reprinted here), by no means is economics the only disciplinary 'origin' in strategic management (see Baum \& Rao, 1998). As Rumelt et al. (1994) point out, strategic management grew not only out of industrial organization and neoclassical economics, but also out of organization theory (Prahalad and Bettis's article, reprinted in this volume, captures some of these other influences well). Indeed, in recent years, research in strategic management has moved increasingly toward a synthesis of economics, organization theory, and behavioral and cognitive psychology. Still, strategic management remains much more influenced by theoretical and analytic traditions in economics than by those in other disciplines, and has yet to be influenced substantively by economic sociology (Baum \& Dutton, 1996). Economic sociologists who, in contrast, view economic action as inherently cultural (DiMaggio, 1990), political (Fligstein \& Mara-drita, 1996), and embedded in structures of social relations (Granovetter, 1985), seek non-price determinants of stable economic arrangements.

\section{Classical Origins of the New Economic Sociology}

The new economic sociology ends a hiatus of sorts in the development of a sociological approach to the economy (see Smelser \& Swedberg 1994; Dobbin forthcoming). From the very start, sociologists were concerned with explaining aspects of economic life. Émile Durkheim's The Division of Labor in Society_(1933), Max Weber's Economy and Society (1978), and Karl Marx's Das Kapital (1894) tackled the structure, nature, and characteristics of the modern economy. The approach was carried forward by C. Wright Mills (1956) and Karl Polanyi (1944), to name just two. Yet from the 1960s, sociologists moved away from explaining economic outcomes per se, such as the conditions that favor the division of labor (Durkheim) or the tendency of competition to lower prices (Marx), and focused instead on explaining "sociological" aspects of economic life.

The rise of neo-classical economics after World War II may be part of the reason for this change. With the decline of institutional economics, economics as a field came to focus not only on economic outcomes, but almost exclusively on economic causes (Yonay 1998). But the shift in sociology also came from within. Talcott Parsons and Neil Smelser (1956) had argued that economic behavior is a special case of social behavior, and hence is subject to the same forces. That idea somehow failed to reinvigorate economic sociology, perhaps because Parsons' own AGIL model, which partitioned the social world in a two-by-two functionalist schema, was so widely influential. A result of the partitioning of the social sciences on the basis of outcome was that sociologists paid less and less attention to explaining economic behavior. Increasingly, economists explained economic behavior with economic causes and sociologists explained social behavior with social causes. For many years, Neo-Marxist sociologists alone crossed the divide.

Gary Becker was one of the first economists to break this barrier, explaining sociological outcomes, such as choice of marriage partners (1976) and racial discrimination (1957), with economic causes. The new economic sociology breaks the barrier from the other side, explaining 
economic outcomes - namely, business strategies -- with sociological causes. Its three main branches build on the work of Weber, Durkheim, and Marx, respectively.

The papers we reprint in this volume extend all three of these traditions. DiMaggio and Powell and Stinchcombe both build on Weber, although on somewhat different elements of his work. White builds on Durkheim, as well as Simmel, and his paper has become a call to action to network theorists in sociology. Fligstein develops a structural theory of power that builds, broadly speaking, on Marx as well as Weber.

The New Institutionalism. Sociological institutionalism follows the Weberian (1978) tradition, focusing on verstehen - the subjective meaning of action -- and on the effects of institutional structure (see Swedberg 1998; Scott 1995). One insight is that subjective meaning underpins human behavior - we behave in ways that are meaningful to us, whether that meaning is associated with salvation or with accumulation. Social behavior necessarily has collective, intersubjective, meaning, for otherwise it would not be social (Meyer \& Rowan 1977; Berger \& Luckmann 1966). Behavior without meaning to the collectivity is treated with psychoactive drugs (and is still left, in Parsons' division of intellectual labor, to psychiatry). One implication is that firms' strategic decisions occur within an institutional context that defines what is 'strategic' and what is not.

A second insight might just as well have been drawn from early institutional economics as from Weber, and it is that existing institutions, such as policy arrangements and management legacies, create both structural and cognitive constraints on firm behavior. Weber refers to these constraints as an "iron cage" (DiMaggio \& Powell 1983). They constrain not only management strategies, by rendering some options impracticable, but managers' imaginations, by rendering some options cognitively unimaginable. Institutional structures are thus inextricable from verstehen, or the meanings people attach to them. Economic behavior in particular is regular and predictable not because it follows universal economic laws, but because it follows institutionalized social scripts. It is thought that economic laws impose only very broad constraints on firms, such that in any given situation, any number of strategies are viable. Thus economic sociology has a lot of variance to explain, and a host of studies has shown that imitation, ideas, and norms play large roles in shaping firm behavior (Mizruchi \& Kim 1999). More and more, these neo-Weberian sociologists are tackling core business strategy (Dobbin 1994). Should your bank diversify into real estate or financial instruments? Haveman (1993) can predict what you'll do by knowing who you mimic -- from whom you learn how to behave. How are venture capital agreements structured in Silicon Valley? Suchman (1995) can predict on the basis of the norms and routines of the intermediaries involved. How do prospective firms decide whether to enter the market? Dobbin and Dowd (1997) can predict on the basis of how the industry interprets the regulatory environment. What predicts the rise of the life insurance sector? Zelizer (1983) shows that a precondition was that it overcome the norm against benefiting from the death of a loved one.

Network Theory. Network theory follows closely in the wake of Durkheim, who was concerned with how social milieu shapes behavior, identity, and social integration. Durkheim described how networks produce social identity, and thereby shape the actions of individuals -- not merely in the negative sense, of undermining anti-social behavior, but in the positive sense, of 
establishing accepted, rational, forms of action. Network theorists critique neo-classical theory's methodological individualism as unrealistic, arguing that it neglects fundamental social processes that shape individual behavior. Like institutional theory, the network theory of Harrison White (1981; 1992) and Mark Granovetter (1985) is phenomenological, in that it focuses on the content of network relations and the meaning of action as defined by the network. Much of the research concerns properties of networks themselves, and how network position can predict economic behavior, net of economic factors. Firms are related through multiple, overlapping, networks: trade association memberships, shared corporate board memberships, professional and managerial networks.

Some see networks as the conduits through which information and ideas travel. How do people find jobs? Granovetter (1972) shows that people find jobs through weak ties rather than strong ones, because actors with strong ties have parallel networks that yield overlapping information. Which firms will give their CEOs golden parachutes? Davis and Greve (1997) predict on the basis of what other firms in the same geographic area are doing. Which firms will embrace matrix management? Burns and Wholey (1993) show that an organization's network predicts. Others emphasize that network structure and position shape behavior. White (1981) argues that market participants get behavioral cues on matters such as pricing not from transaction partners but from peers who share their structural position. Baker (1984) shows that small groups of stock traders achieve more competitive prices than do large groups, because small groups enjoy superior information flows. Burt (1992) shows that firms with better network connections (with no "structural holes" surrounding them) are more successful, particularly if they are connected to firms that themselves are surrounded by structural holes. Uzzi (1999) shows that firms receive lower interest rates when they have network ties to a bank. Palmer et al. (1995) find that firms with interlocks to commercial banks were better able to fend off hostile predators in the 1960s. Mizruchi and Stearns (1994) show that firms with bankers on their corporate boards are more likely to borrow money.

The Structural Theory of Power. The structural theory of power can be traced to Marx. Here the concern is with how powerful groups manage to get their way, using force and persuasion to promote the management practices and public policies they favor. These groups succeed not by force alone, but by promoting what Marxists used to call "false consciousness" to convince people that what is in their own interest is actually in the common (corporate or national) interest. This approach to power descends from C.Wright Mills' The Power Elite (1956), which suggests that a political/economic elite controls the state and corporation, as well as from modern theories of power, such as Stephen Lukes' (1974) Power: A Radical View, which suggests that in modern polities, powerful groups exercise control by controlling the agenda of the political debate. One stream of research explores the structure and influence of the corporate elite, and is the direct legacy of Mills (Useem 1984; Mintz \& Schwartz 1985). Among this group, a number have used corporate board interlocks, and composition, to explain business strategy. The idea is that elite networks develop strategies collectively, and thereby shape firm strategy. Empirical findings overlap with those of network theorists. Palmer, Jennings, and Zhou (1993) show that firms with ties to multi-divisional firms are more likely to adopt that structure. Davis (1991) shows that firms with ties to others that have adopted the poison pill are more likely to adopt the poison pill themselves. Baysinger and Butler (1985) find that firms with more outside directors 
are more profitable. Mizruchi and Stearns (1988) find that unprofitable firms appoint bankers to their boards, evidently to improve monitoring of the management team.

A second group is more directly concerned with the exercise of power in the historical formation of regulatory regimes and business strategies. How was horizontal integration popularized?

Diversification? Identifiable actors promoted these strategies, and they typically had something to gain. Once institutionalized, new regulations and business strategies reinforce the groups that promoted them. In The Transformation of Corporate Control Fligstein (1990) argues, with institutionalists, that such exogenous shocks as regulatory shifts spawn new business strategies. A power struggle among competing management groups - marketing versus finance managers, for instance - often determines corporate response (for an update, see Ocasio \& Kim 1999). The group that wins control of the firm may direct future decisions for some time to come. In Socializing Capital, Roy (1997) shifts the emphasis to the struggle for control among corporations. In tackling the merger wave circa 1900 - Alfred Chandler's terrain - Roy argues that mergers and acquisitions were not necessarily efficient, rather they were forced upon small business by big firms and financiers threatening cut-throat competition. The strategy of horizontal acquisitions thus spread in industries in which it was efficient as well as in industries in which it was not. Both of these approaches make the connection between institutions and power, and in both directions. That is, institutional arrangements influence who is able to exercise power to get their way - to promote the business strategy they favor. Once new business strategies are institutionalized, they reinforce the power of their proponents.

Reading an isolated piece by an institutional, network, or power theorist is still a bit like touching part of an elephant when blindfolded. It's very difficult to envision the whole - the sociological perspective that binds them together. While each group focuses on a different aspect of the sociological formation of business strategy, the three do usually agree on the big picture. Economic practices - behavior patterns such as pricing strategies and firm structures - emerge in networks of actors, via the social construction of scripts for how to achieve particular ends. Powerful actors try to shape the scripts that are constructed, and to shape the rules of the game that become institutionalized in public policy. Economic practices, or scripts, shape individual cognition, determining how people will respond to new situations. In other words, economic practices emerge through distinctly social processes in which social networks and power resources play roles in the social construction and cognitive representation of certain actions as rational.

One can see the theoretical integration of these approaches in the work of many people in the field. Harrison White has always used a social constructionist view of behavior in his network theory, to explain how norms about pricing are socially produced. Patrick McGuire and Mark Granovetter (forthcoming) use a structural theory of power in their network study of electricity generation to explain technological choices. Institutionalists, like David Strang and John Meyer (1993), use a form of network theory to explain how business practices diffuse. Structural theorists of power - particularly Bill Roy and Neil Fligstein -- have incorporated both institutional and network elements to explain how new norms diffuse across corporations. In short, rather than seeking to disprove the other paradigms, as is typical in a multi-paradigmatic field such as sociology, leaders in each of these fields are borrowing liberally. 
Does Efficiency Matter? These economic sociologists share a sort of skepticism about the primacy of efficiency in the process of corporate change. Most grant that efficiency of one sort or another drives managerial decisions, although some contend, along with agency theorists in economics, that managers may act in their own, narrow, interest. Yet sociologists tend to presume that managers act with poor information about the efficiency of prospective strategies, and that markets do not efficiently destroy firms that make bad calls (Meyer \& Zucker 1989). On the one hand, most firms make a mix of good and bad decisions, such that a disastrous strategy in production may be alleviated by a good one in marketing, or in human resources. On the other hand, firms that seek in earnest to copy their profitable peers may have difficulty figuring out what to copy, and may have difficulty copying it (as sociologist-turned-strategist Jay Barney points out in this volume). Sociologists certainly see managers as striving for efficiency. But given the vagaries of management decisions, they focus on how sociological processes lead managers to choose from a litany of alternatives. Finally, institutionalists, in particular, argue that firms succeed by following the current strategic scripts - that doing what is hot may work primarily by signaling to buyers and investors that you, yourself, are hot (Meyer \& Rowan 1977).

\section{The Papers}

Next we turn to the four sets of articles. In each pair, the two articles address the same broad phenomenon. We outline some of the key differences in approach. The essays and comments that follow the articles cover a wide range of issues, and they convey a much more thorough sense of the strengths and weaknesses of each discipline. Here we focus on the articles, rather than the original essays and comments, so as not to steal the authors' thunder. As you will soon see, they are, without exception, entertaining, intelligent, and provocative.

\section{An Embarrassment of Riches: Teece and Fligstein}

We paired the Teece and Fligstein papers, which derive from two very influential lines of research, because both seek to explain diversification.(3) Why have so many firms moved into new products and services, rather than expanding production in their original fields or returning profits to shareholders? Teece and Fligstein develop theories about different parts of this change, with Teece focusing on the multiproduct strategy itself and Fligstein focusing on a common byproduct, the multi-divisional firm. Their answers differ substantially, as we noted above. Fligstein's work is emblematic of the structural theory of power found in sociology, and Teece's paper helped to bring transaction cost economics squarely into the field of management. Because we outlined the arguments found in these papers above, here we simply note two differences in approach.

First, Teece's approach is deductive; whereas Fligstein's is inductive. Teece observes multiproduct firms, and then derives arguments from transaction cost economics to explain them. Fligstein observes the rise of the M-form firm, and then acts as an historical detective to develop a theory. At first light, this seems to be a fundamental difference. But in practice, the deductive and inductive approaches may not be so very far apart. Teece is, after all, developing a theory to 
explain real-world behavior he has observed. Fligstein is, after all, building on existing sociological theories of power and institutions. Thus, while strategy and economic sociology may expound different approaches, with strategists from economics aspiring to derive theories from first principles and economic sociologists aspiring to derive theories from direct observation of behavior, in practice, both fields may do a little of each.

Second, Teece and Fligstein differ in what they set aside, or hold constant. Teece presumes that a business strategy that has grown in popularity must be marginally more efficient than that which it replaced - the proof is in the pudding, the new strategy has won -- and develops a theory of the efficiency of that strategy. He sets aside the social mechanisms behind the change, in trying to explain as much of the variance as possible with economic theory. Fligstein assumes that a strategy must have diffused as a consequence of an identifiable social process, and develops a theory of how institutions and power played a role in the diffusion of a practice. He sets aside the issue of the relative efficiency of the new practice, in the belief that efficiency alone cannot explain its success.

In other words, strategic management theorists often treat the social processes by which a new strategy diffuses as a "black box." Sociologists contend that understanding what goes on in the black box is key to understanding why certain efficient strategies take hold, while others wither. For instance, Fligstein contends that the Celler-Kefauver amendments to antitrust law, which made both horizontal and vertical mergers difficult, stimulated firms to diversify. This begs the question: is the Celler-Kefauver act a scope condition for Teece's theory - a necessary condition? Can the theory travel to Germany, or South Korea?

By contrast, economic sociologists often treat the efficiency of a practice as immaterial to its survival. When they deal with efficiency, it is often as rhetoric rather than as reality, for they believe, along with March and Simon, that managers do not make decisions with full information. And they believe that managers are not prophets, and cannot know which of several prospective strategies will be optimal. But sociologists neglect efficiency at their own peril, for managers do strive to improve efficiency and they do sometimes "get it right". Understanding how executives judge the relative efficiency of strategies, and what determines when their judgements are correct, is key to understanding strategic choice. If diversification went too far, as the new "core competence" movement suggests, for what kinds of firms was it a good idea, and why did other firms join the bandwagon?

\section{All Happy Firms are the Same: Pralahad and Bettis, DiMaggio and Powell}

"The Dominant Logic" is the one strategy paper we reprint that has its roots in psychology, rather than in economics, and it has become one of the most widely referred to papers at the intersection of psychology and strategy. "The Iron Cage Revisited" is one of the two papers, with Meyer and Rowan's (1977) "Institutionalized Organizations", that spawned the "new institutionalism" in organizational sociology. On the surface these two papers seem to share little. Pralahad and Bettis explain why some firms are able to make diversification profitable. DiMaggio and Powell explain why firms develop identical structures and practices. The causes appear, at first blush, to be far apart as well. Pralahad and Bettis point to factors internal to the firm, and develop arguments from cognitive psychology to explain management logics. 
DiMaggio and Powell point to factors external to the firm, and develop arguments from Weberian sociology to explain the decline of variance in management styles.

Yet at their cores, these papers describe a common phenomenon. Both seek to understand how management practices and the rationales that underlie them emerge. Pralahad and Bettis argue that firms develop management logics locally through experience, and incidentally that one kind of logic is superior for running a diversified firm. DiMaggio and Powell suggest that organizations copy management practices and rationales from their peers. While the two duos focus on different aspects of management patterns - the cognitive component in the first case and the structural component in the second -- both see cognition as reflective of structure. Thus, at their core, both papers address how different management strategies, and the cognitive orientations that underlie them, arise.

Their broad explanatory models are based in psychology and sociology, respectively. Pralahad and Bettis see the history of the firm much as the psychologist sees the history of the individual. Experience shapes the individual's (firm's) perceptions of the world and ways of dealing with the world. Individuals (firms) with similar experiences will have similar ways of operating in the world. Individuals (firms) who function well under one, stable, set of circumstances may function poorly when circumstances are altered (e.g., after diversification). DiMaggio and Powell see the socialization of the firm as parallel to the socialization of the individual. Individuals (firms) develop their ways-of-being through socialization. They copy the behavior of others, and are most likely to copy those they admire, or those who exercise control over them. Under each of these views, firm practices shape, and are shaped by, individual cognition (see DiMaggio 1997 for a review that links cognition to institutions). Continuity in firm practices operates via a sort of feedback loop, in which a strategy that is institutionalized in structure becomes institutionalized in cognition, and new strategies are shaped by that cognition.

These two papers thus illustrate how shifting the focus from the individual to the collectivity alters how we describe the firm. Both duos are trying to explain dominant business logics, which consist of mindsets and concrete business practices. In practice, firms, like individuals, are shaped both by their own experiences and by their exposure to the behavior of others. A textile firm, or web browser start-up, develops a managerial logic based on its own experience, including its social experience. It copies successful peers (mimetic isomorphism), is advised by management consultants (normative isomorphism), and is constrained by public policies (coercive isomorphism).

\section{Where All the Firms are Above Average: Barney and Stinchcombe}

We matched Barney and Stinchcombe because both are concerned with "path dependence" -- the fact that even in the face of environmental pressure, firm strategies and forms tend to persist. Both challenge the idea that competitive pressures will lead firms to adopt strategies that are optimal for the business at hand. Stinchcombe is responding to the functionalist assumption in sociology that firms will evolve as the technology of organizing evolves, adopting new, appropriate forms as they appear. His view is consistent with Weber's vision of the "iron cage", and it shares the structural approach to organizational continuity found in the early institutionalism of Philip Selznick (1957). He argues that entire industries tend to be organized 
using the social and physical technologies that prevailed when they were founded. Pressure for change is small when all industry participants use more or less the same technology. Initial strategies persist even when new, more efficient technologies become available. Barney is responding to the emphasis, in strategic management, on the environmental factors that favor strong firm performance. The corresponding neglect of firm-level factors is based in the assumption that organizational advantages are fleeting, because the resources that underlie them are mobile. He makes the case that organizational advantages are sticky, and that this is the source of continuity in competitive advantage. In short, both Stinchcombe and Barney describe a situation in which firms faced with potentially superior strategies and practices do not change. This observation poses a quandary for the conventional view of the firm, in which markets force managers to remain on the lookout for better ways of doing business.

Stinchcombe and Barney have different views of the pressure for change. Stinchcombe focuses on heterogeneity across industries. Industries follow the strategies and practices that were popular when they were founded, such that industries founded in the age of Fordism will have Fordist assembly lines, and industries founded in the age of the craft workshop will be so organized. Sometimes implicit in Stinchcombe's account is the absence of competitors using new and improved strategies. If you are in a craft industry that could potentially use assembly-line techniques, you only face the imperative to change if you face competitors who have assembly lines. Population ecologists built on Stinchcombe's insight that firms do not easily change their ways. In their view, organizational change occurs largely through the birth and death of firms rather than through adaptation - firms that are poorly suited to their environments tend to die, rather than to change (see Baum 1996 for a review; Aldrich 1999 for an evolutionary view of change). Many others have documented persistence, for instance Baron, Hannan, and Burton (1999) find that the management orientation of a firm's founder persists beyond the founder's tenure.

Barney focuses not on heterogeneity across industries, but on heterogeneity across firms within industries. He suggests that competitive pressures do not cause firms with competitive disadvantage to mirror their successful peers. Because the fundamentals underlying advantage are not fully mobile, they do not move readily across firms and thus differences in success can persist over long periods. Stinchcombe's tacit argument seems broadly economic; whereas Barney's explicit argument is sociological. As DiMaggio and Powell argue in the paper we reprint, firms do their best to mimic success cases, but it is often difficult to figure out what to copy. Is it the slick advertising? Is it the throughput system? Barney suggests that firm differences are sustained because the cause of success is ambiguous, and because it may depend on a complex set of arrangements that are, in their complexity, essentially inimitable. Firm resources that generate profits are built from local experience and knowledge (Nelson \& Winter 1982), and even if you can pinpoint them you may be unable to imitate them.

Despite their shared view of the continuity of firm practices, Stinchcombe and Barney use characteristically different modes of explanation. The differences have, in part, to do with the relationship between theory and action. In sociology, the goal is to develop explanatory models of behavior. In strategic management, this goal is supplemented with the goal of developing prescriptions for action. While both papers are theoretical rather than empirical or prescriptive, 
Stinchcombe offers hypotheses for business historians to test; whereas Barney offers hypotheses for managers to contend with.

These differences reflect the respective fields. Real strategic advantage, as opposed to happenstance, is the consequence of finding an especially good way of doing business. From this perspective, the typical sociological approach - of collecting longitudinal data from large numbers of firms and running multivariate models - comes too late in the game. The game is already over if there are enough companies to form an experimental group and a control group. The key practical problem is to be one of the first to identify the strategy and build it into your business model. Economic sociologists favor large, longitudinal, datasets that allow them to test competing theories in a single model, excluding some theories, controlling for others, and identifying the net effects of others. In his comment, Stinchcombe implies that focusing on winners is not good social science, because it constitutes sampling on the dependent variable. This is all well and good if the goal is a history of management, but if the goal is practical advice for managers the post hoc approach may highlight successful strategies too late in the game.

\section{Finding Your Niche: Oster and White}

We paired White's "Where do markets come from?" with Oster's "Intraindustry structure and the ease of strategic change" because both are concerned with how a diversity of strategies within an industry emerges and persists, and both suggest that producers develop strategies by observing the behavior of other producers rather than, as price theory suggests, by observing the behavior of buyers. As Oster (1982: 36) argues: "When firms enter a business, they observe several alternative ways of conducting that business. ... One firm decides to advertise a high quality product; a second decides to pursue a high volume line." In White's (1981: 518) words: "what a firm does in a market is to watch the competition in terms of observables." Both are concerned with how disparate strategies within industries develop -- with how a firm decides to focus on quality and brand recognition, or on volume and price. With how, in White's words, a firm develops an identity and a unique market position. With how, in Oster's words, a firm chooses which "strategic group" to join.

White's orientation is Durkheimian, and the paper we reprint here is one of the cornerstones of network theory in sociology. He describes managers as developing firm identity and strategy not by looking across the buyer-seller divide to see how their exchange partners are behaving, but by looking at their peers. A firm's strategy and price emerge as it develops an identity vis-à-vis its peers in the industry, seeking a set of business practices that will shield it from competition. The core idea is consonant with Spence's (1974) arguments about signaling (on Spence's wider influence, see Vaughan 1998). Here, firms signal their strategies to one another, and changes in $a$ 's strategy can lead to changes in $b$ 's, although $b$ is more likely to differentiate itself from $a$ than to imitate $a$. White suggests that strategic behavior, like other forms of behavior, is inherently relational. Firms develop unique identities (strategies) within markets, in relation to other firms in the market. White thus challenges the neo-classical view of the market, which defines buyerseller interactions as key.

Oster's theory combines insights from business policy and the behavioral theory of the firm. The central empirical observation is that industries often develop a diversity of successful strategies, 
and that in some industries, differences among firms can be quite stable. A new entrant typically selects from the menu of existing strategies, based on an assessment of which strategy corresponds with unmet consumer demand. Early decisions produce lock-in, making it difficult for firms to switch strategies because of sunk costs and established market position. There is inevitably pressure to switch to the highest-performing strategic group, but the costs of switching can be high. Oster speculates that in consumer goods, groups are defined by their advertising strategies, and shows that high-advertising firms and low-advertising firms tend to persist in their strategies, unless some disturbing force - a downturn in profits - leads them to rethink their strategy.

In White's model of the world, a firm observes its peers and develops a unique relational identity, filling a specific niche. The goal is to fill a niche that will be shielded from competition, by pursuing a strategy that does not exactly match that of any other firm. For White, a firm's identity within the industry network is dependent on the identities (in terms of quality of product, volume, price, etc.) of other firms. In Oster's model of the world, firms entering a market imprint on existing firms in the field, choosing a strategy off the shelf. The goal is to select a strategy from among observable options that is suited to demand. In both models, a single market typically contains firms pursuing a diversity of strategies (identities), which are developed relationally, as firms observe the strategies (identities) of their peers.

Both White and Oster develop insights that might have come from either economics or sociology. Oster's model of the firm is fundamentally sociological, in that firms are social actors following the behavior of their peers. White's model might have developed out of industrial organization theory, in that the focus is on how firms try to shield themselves from competition.

But the papers highlight a fundamental difference in methodological conventions between the two fields, and this becomes particularly clear in the comments. That difference is rooted in the basic assumptions of the two fields. In his comment, White argues that Oster, like her peers in economics, does not directly observe the strategic choices of firms by, for instance, interviewing executives. For that matter, observed motive is not a focus in White's paper either, but the critique lays bare an important epistemological difference between the fields. Following $\mathrm{C}$. Wright Mills' sociological invective against "abstract empiricism", quantitatively oriented sociologists have increasingly looked for qualitative verification of the motives underlying action. The convention among economists, by contrast, is to observe whether data suggest that people behave as if theoretical models are valid. Conscious motives have been key for sociologists ever since Weber implored us to pay attention to the meaning of action to the actor. Economists tend to see conscious motives as immaterial, in the belief that people can behave rationally without being able to articulate why their actions are rational. Thus the best evidence is not evidence about motives, but evidence about behavior. If behavior follows the predictions of a theory, the theory holds. These different basic assumptions lead to a very different relationship between theory and evidence in the two fields. Sociologists assume that actors may lie about their motives, but they also assume that actors understand their own motives well. Most economists make no such assumption.

\section{Great Minds Think Alike}


Although we chose the papers to highlight differences between the two fields, in hindsight, we were struck by the number of common ideas across the papers. In both fields, researchers develop their ideas in part by observing the actual behavior of firms. This may be why the two fields have, independently, come to some very similar conclusions. The idea that firms model their strategies after others is found in DiMaggio and Powell, as well as in Oster. The idea that firms develop strategies by observing peers, rather than transaction partners, is found in Oster and White. The idea that firms mimic the behavior of successful peers, but face great uncertainty about what to mimic, is found in Barney as well as in DiMaggio and Powell. The idea that firms develop stable identities that may be resistant to change is found in White, Stinchcombe, Barney, and Oster. The idea that a modus operandi (dominant logic or conception of control) prevails within the firm and can be toppled by exogenous shocks is found in both Fligstein and Barney. We could go on here, but we simply wish to draw attention to the substantial common ground found among the two fields, despite their differences. The differences are spelled out colorfully in the essays and commentaries that follow each pair of articles.

\section{Conclusion}

While strategists and sociologists address the same broad phenomena - the behavior of the firm - different disciplinary customs and preferences have kept them apart. In strategic management, the central goal is to develop adequate theories of why certain strategies are successful. This has led to the application of theories from the various foundational disciplines -- economics, and to a lesser extent psychology and sociology. Analysts observe exemplary cases with the goal of teasing out the key strategic factors that underlie success. They ask: What makes HewlettPackard work? In economic sociology, the principal goal is to refine multi-paradigmatic models of firm behavior, adding new insights and variables to existing models. This has led to the application of theories traceable to three founders of sociology, Weber, Durkheim, and Marx. Analysts observe broad trends among corporations with the goal of identifying their social, political, and historical origins. They ask: Why has "core competence" caught on here and now?

Despite the fact that they are ostensibly oriented to theorizing efficiency in one case and to explaining common firm strategies in the other, in practice both fields seek to explain particular strategic decisions. While sociologists generally try to explain decisions in terms of regulation, power, and social milieu, strategists generally try to explain decisions in terms of their competitive advantage. Strategists tend, that is, to work backward from firm performance, explaining a practice by its superiority of effect rather than by the factors that predict its adoption.

These approaches are quite different, yet they have often led to similar insights about the workings of the firm, as we have duly noted. We suggested at the outset that each perspective offers only a partial view of the firm. We hope that readers will, after reading the contributions that follow, agree that together the two perspectives provide a fuller, and more threedimensional, view of the firm. 
We bring the two fields together in the conviction that they have much to learn from one another, and that exchange may lead each field to develop richer and more compelling understandings of corporate behavior. The two groups have sparred at times in print. In the articles reprinted herein we give readers a chance see how the two fields approach four different issues. In the essays and comments that follow we give leaders in the two fields a chance to stand back and consider their differences. The result, we believe, is an informative, intelligent, and provocative overview which, we hope, will help to open a broad, ongoing dialogue.

\section{Endnotes}

1. Industries characterized by significant scale economies, for example, will support only a few, large competitors and will not be easily penetrated by small entrants. High concentration in scale economy-based industries may lead rivals to compete less fiercely, resulting in higher profits. And, even if incumbent rivals are earning strong profits, the greater difficulty of entry reduces the likelihood that new firms will enter the market.

2. Since the emergence of the field of strategic management, industrial organization economics has increasingly devoted its attention to the analysis of rivals' strategic -- self-consciously interactive -- behavior. However, behavior that is strategic in this sense has not been a primary concern of strategic management -- and there appears to be considerable skepticism within strategic management about the value of contemporary, game-theoretic, industrial organization (Camerer, 1991; Rumelt et al., 1994; but see Ghemawat, 1991).

3. Fligstein's paper presents a synopsis of the argument found in his 1990 book, and presaged in a series of journal articles (e.g., Fligstein 1985). Teece's paper extends a line of research he developed in another journal article (Teece 1980).

\section{References}

Aldrich, Howard. 1999. Organizations Evolving. Thousand Oaks, CA: Sage.

Armour, H.O. and D. J. Teece. 1978. "Organizational structure and economic performance: A test of the multidivisional hypothesis." Bell Journal of Economics, 9: 106-122.

Bain, J. S. 1956. Barriers to New Competition. Cambridge MA: Harvard University Press.

Baker, Wayne. 1984. "The Social Structure of a National Securities market." American Journal of Sociology, 89:775-811.

Barney, J. B. 1991. "Firm resources and sustained competitive advantage." Journal of Management, 17: 99-120. 
Baron, James N., Michael T. Hannan, and M. Diane Burton. 1999. "Building the Iron Cage: Determinants of Managerial Intensity in the Early Years of Organizations." American Sociological Review, 64: 527-547.

Baum J.A.C., and H. Rao. 1998. "Strategic management as a fish-scale multiscience." In J.A.C. Baum (ed.) Disciplinary Roots of Strategic Management (Advances in Strategic Management, Vol. 15): 1-16. Stamford CT: JAI Press.

Baum, J.A.C. and J.E. Dutton. 1996. "The embeddeness of strategy." In J.A.C. Baum and J.E. Dutton (eds.) The Embeddeness of Strategy (Advances in Strategic Management, Vol. 13): 1-15. Stamford CT: JAI Press.

Baum, Joel A.C. 1996. "Organizational ecology." In Steward R. Clegg, Cynthia Hardy, and Walter Nord (eds.), Handbook of Organization Studies. Pp. 74-114. London: Sage.

Baysinger, Barry D. and Butler, H.N. 1985. "Corporate Governance and the Board of Directors: Performance Effects of Changes in Board Composition." Journal of Law and Economic Organization, 1: 101-24.

Becker, Gary. 1957. The Economics of Discrimination. Chicago: University of Chicago Press.

Becker, Gary. 1976. The Economic Approach to Human Behavior. Chicago: University of Chicago Press.

Berger, Peter, and Thomas Luckmann. 1966. The Social Construction of Reality: A Treatise on the Sociology of Knowledge. Garden City: Doubleday.

Bogner, W.C., J.T. Mahoney \& H. Thomas. 1998. "Paradigm shift: The parallel origin, evolution, and function of strategic group analysis with the resource-based theory of the firm." In J.A.C. Baum (ed.) Disciplinary Roots of Strategic Management (Advances in Strategic Management, Vol. 15): 63-102. Stamford CT: JAI Press.

Burns, Lawton R. and Douglas R. Wholey. 1993. "Adoption and Abandonment of Matrix Management Programs: Effects of Organizational Characteristics and Interorganizational Networks." Academy of Management Journal, 36: 106-38.

Burt, Ronald S. 1992. Structural Holes. Cambridge MA: Harvard University Press.

Caves, R. E. and M.E. Porter. 1977. "From entry barriers to mobility barriers: Conjectural decisions and contrived deterrence to new competition." Quarterly Journal of Economics, 91: 241-261.

Chandler, A.D., Jr. 1962. Strategy and Structure: Chapters in the History of the Industrial Enterprise.Cambridge MA: MIT Press.

Coase, R.H. 1937. "The nature of the firm." Economica, 4: 386-405. 
Cool, K O. and D.E. Schendel. 1987. "Strategic group formation and performance: The case of the U.S. pharmaceuticals industry, 1963-1982." Management Science, 1102-1124.

Davis, Gerald F., and Henrich R. Greve. 1997. "Corporate Elite Networks and Governance Changes in the 1980s." American Journal of Sociology, 103: 1-37.

Davis, Gerald F., Kristina A. Diekmann, and Catherine H. Tinsley. 1994. "The decline and fall of the conglomerate firm in the 1980s: The deinstitutionalization of an organizational form." American Sociological Review, 59: 547-570.

Davis, Gerald. 1991. "Agents without Principles: The Spread of the Poison Pill through the Intercorporate network." Administrative Science Quarterly, 36: 583-613.

Demsetz, H. 1973. "Industry structure, market rivalry, and public policy." Journal of Law and Economics, 16: 1-10.

DiMaggio, Paul J. 1997. "Culture and Cognition." Annual Review of Sociology, 23: 263-87.

DiMaggio, Paul J. and Walter W. Powell. 1983. "The Iron Cage Revisited: Institutional Isomorphism and Collective Rationality in Organizational Fields." American Sociological Review, 35:147-60.

Dobbin, Frank. Forthcoming. The New Economic Sociology: An Anthology. Princeton, NJ: Princeton University Press.

Dobbin, Frank. 1994. "Cultural Models of Organization: The Social Construction of Rational Organizing Principles." Pp. 117-141 in Sociology of Culture: Emerging Theoretical Perspectives. Edited by Diana Crane. Oxford: Basil Blackwell.

Dobbin, Frank and Timothy Dowd. 1997. "How Policy Shapes Competition: Early Railroad Foundings in Massachusetts." Administrative Science Quarterly 42: 501-529.

Durkheim, Émile. 1933. The Division of Labor in Society. George Simpson (trans.). New York: Free Press.

Dyer, J.H. and H. Singh. 1998. "The relational view: Cooperative strategy and sources of interorganizational competitive advantage." Academy of Management Review, 23: 660-679.

Fligstein, Neil and Iona Mara-Drita. 1996. "How to Make a Market: Reflections on the Attempt to Create a Single Market in the European Union." American Journal of Sociology, 102: 1-33.

Fligstein, Neil. 1985. "The Spread of the Multidivisional Form among Large Firms, 1919-1970." American Sociological Review, 50:377-91.

Fligstein, Neil. 1990. The Transformation of Corporate Control. Cambridge, MA: Harvard University Press. 
Foss, N.J. 1996. "Knowledge-based approaches to the theory of the firm: Some critical comments." Organization Science, 7: 477-501.

Ghemawat, P. 1991. Commitment: The Dynamic of Strategy. New York: Free Press.

Granovetter, Mark. 1972. Getting a Job: A Study of Contacts and Careers. Cambridge: Harvard University Press.

Granovetter, M. 1985. "Economic action and social structure: The problem of embeddedness." American Journal of Sociology, 91: 481-510.

Hatten, K.J. and D. E. Schendel. 1977. "Heterogeneity within an industry: Firm conduct in the U.S. brewing industry, 1952-1971." Journal of Industrial Economics, 26: 97-113.

Haveman, Heather A. 1993. "Follow the Leader: Mimetic Isomorphism and Entry into New Markets." Administrative Science Quarterly, 38:593-627.

Kogut, B. 1988. "Joint ventures: Theoretical and empirical perspectives." Strategic Management Journal, 9: 319-332.

Lippman, S.A. and R.P. Rumelt. 1982. "Uncertain imitability: An analysis of interfirm differences in efficiency under competition." Bell Journal of Economics, 13: 418-438.

Lukes, Steven. 1974. Power: A Radical View. London: Oxford University Press.

Mahoney, J.T. and J.R. Pandian. 1992. "The resource-based view within the conversation of strategic management." Strategic Management Journal, 13: 559-584.

Marx, Karl. 1894. Das Kapital. Three Volumes. New York: International Publishers.

Mason, E.S. 1957. Economic Concentration and the Monopoly Problem. Cambridge MA: Harvard University Press.

Masten, Scott E., and James W. Meehan, Jr. 1989. "Vertical Integration in the U.S. Auto Industry: A Note on the Influence of Transaction Specific Assets." Journal of Economic Behavior \& Organization, 12: 265-274.

Masten, S.E. 1993. "Transaction costs, mistakes, and performance: Asessing the importance of governance." Managerial and Decision Economics, 14: 119-129.

McGuire, Patrick and Mark Granovetter. Forthcoming. The Social Construction of Industry: Human Agency in the Development, Diffusion, and Institutionalization of the Electric Utility Industry. New York: Cambridge University Press.

Meyer, Marshall W. and Lynne G. Zucker. 1989. Permanently Failing Organizations. Newbury Park, CA: Sage. 
Meyer, John W., and Brian Rowan. 1977. "Institutionalized Organizations: Formal Structure as Myth and Ceremony." American Journal of Sociology, 83:340-63.

Mills, C. Wright. 1956. The Power Elite. New York: Oxford University Press.

Mintz, Beth and Michael Schwartz. 1985. The Power Structure of American Business. Chicago: University of Chicago Press.

Mizruchi, Mark C. and Linda Brewster Stearns. 1988. "A Longitudinal Study of the Formation of Interlocking Directorates." Administrative Science Quarterly, 33: 191-210.

Mizruchi, Mark C. and Linda Brewster Stearns. 1994. "A Longitudinal Study of Borrowing by Large American Corporations." Administrative Science Quarterly, 39: 118-141.

Mizruchi, Mark S. and Lisa C. Fein. 1999. "The Social Construction of Organizational Knowledge: A Study of the Uses of Coercive, Mimetic, and Normative Isomorphism." Administrative Science Quarterly, 44: 653-683.

Mosakowski, E. 1993. "A resource-based perspective on the dynamic strategy-performance relationship: An empirical examination of the focus and differentiation strategies in entrepreneurial firms." Journal of Management, 19: 819-839.

Nelson, Richard and Sidney Winter. 1982. An Evolutionary Theory of Economic Change. Cambridge, Massachusetts, Harvard University Press.

Ocasio, William 1997. "Towards an Attention-Based View of the Firm." Strategic Management Journal, 18 (Summer Special Issue): 187-206.

Ocasio, William and Hyosun Kim. 1999. "The circulation of Corporate control: Selection of Functional Backgrounds of New CEOs in Large U.S. Manufacturing Firms, 1981-1992." Administrative Science Quarterly, 44: 532-562.

Oster, S. M. 1982. "Intraindustry structure and the ease of strategic change." Review of Economics and Statistics, 64: 376-383.

Palmer, Donald, Brad M. Barber, Xueguang Zhou, and Yasemin Soysal. 1995. "The Friendly and Predatory Acquisition of Large U.S. Corporations in the 1960s: The Other Contested Terrain." American Sociological Review, 60: 469-500.

Palmer, Donald, P. Devereaux Jennings, and Xueguang Zhou. 1993. "Late Adoption of the Multidivisional Form by Large U.S. Corporations: Institutional, Political, and Economic Accounts." Administrative Science Quarterly, 1993: 100-131.

Parsons, Talcott and Neil Smelser. 1956. Economy and Society: A Study in the Integration of Economic and Social Theory. London: Routledge and Kegan Paul. 
Penrose, E.T. 1959. The Theory of the Growth of the Firm. New York: John Wiley \& Sons.

Peteraf, MA. 1993. "The cornerstones of competitive advantage: A resource-based view." Strategic Management Journal, 14: 179-191.

Pisano, G.P. 1990. "The R\&D boundaries of the firm." Administrative Science Quarterly, 34: 153-176.

Polanyi, Karl. 1944. The Great Transformation: The Political and Economic Origins of Our Time. New York: Rinehart.

Porter, M.E. 1979. "The structure within industries and companies' performance." Review of Economics and Statistics, 61: 214-227.

Porter, M.E. 1980. Competitive Strategy: Techniques for Analyzing Industries and Competitors. New York: Free Press.

Ricardo, D. 1917. Principles of Political Economy and Taxation. London: J. Murray.

Roy, William G. 1997. Socializing Capital: The Rise of the Large Industrial Corporation in America. Princeton, NJ: Princeton University Press.

Rumelt R.P. 1991. "How much does industry matter?" Strategic Management Journal, 12: 167185.

Rumelt, R.P. 1984. "Toward a strategic theory of the firm." In R. Lamb (ed.) Competitive Strategic Management: 556-570. Englewood Cliffs NJ: Prentice-Hall.

Rumelt, R.P., D.E. Schendel, and D.J. Teece. 1994. "Fundamental Issues in Strategy." In R.P. Rumelt, D.E. Schendel, and D.J. Teece (eds.) Fundamental Issues in Strategy: A Research Agenda: 9-47. Boston: Harvard Business School Press.

Scott, W. Richard. 1995. Institutions and Organizations. Sage: Thousand Oaks, CA.

Schumpeter, J. A.1934. The Theory of Economic Development. Cambridge MA: Harvard University Press.

Selznick, Philip. 1957. Leadership in Administration. New York: Harper and Row.

Spence, A. Michael. 1974. Market Signaling: Informational Transfer in Hiring and Related Screening Processes. Cambridge, MA: Harvard University Press.

Stigler, G. 1968. The Organization of Industry. Chicago: University of Chicago Press.

Strang, David, and John W. Meyer. 1993. "Institutional Conditions for Diffusion." Theory and Society, 22: 487-511. 
Suchman, Mark. 1995. "The Contracting Universe: Law Firms, Venture Capital Funds, and the Institutionalization of New-Company Financing in Silicon Valley." Paper presented at the Annual Meetings of the American Sociological Association.

Smelser, Neil and Richard Swedberg. 1994. "The Sociological Perspective on the Economy." Pp. 3-26 in The Handbook of Economic Sociology. Princeton, NJ : Princeton University Press.

Swedberg, Richard. 1998. Max Weber and the Idea of Economic Sociology. Princeton, NJ: Princeton University Press.

Teece, D.J. 1982. "Towards an economic theory of the multi-product firm." Journal of Economic Behavior and Organization, 3: 39-63.

Teece, D.J. and G. Pisano, 1994. "The dynamic capabilities of firms: An introduction." Industrial and Corporate Change, 3: 537-556.

Teece, D.J., G. Pisano and A. Schuen. 1997."Dynamic capabilities and strategic management." Strategic Management Journal, 18: 509-533.

Teece, David J. 1980. "Economies of Scope and the Scope of the Enterprise." Journal of Economic Behavior and Organization, 1:223-247.

Useem, Michael. 1984. The Inner Circle. New York: Oxford University Press.

Uzzi, Brian. 1999. "Embeddedness in the Making of Financial Capital: How Social Relations and Networks Benefit Firms Seeking Financing." American Sociological Review, 64: 481-505.

Vaughan, Diane. 1998. "How Theory Travels: Analogy, Models, and the Case of A. Michael Spence." Paper presented at the Annual Meetings of the American Sociological Association, San Francisco.

Walker, G. and D. Weber. 1984. "A transaction cost approach to make or buy decisions." Administrative Science Quarterly, 29: 373-391.

Weber, Max. 1978. Economy and Society. Two Volumes. Edited by Guenther Roth and Claus Wittich. Berkeley: University of California Press.

Wernerfelt, B. 1984 "A resource-based view of the firm." Strategic Management Journal, 5: 171-180.

White, Harrison C. 1992. Identity and Control: A Structural Theory of Social Action. Princeton, NJ: Princeton University Press.

White, Harrison C. 1981. "Where Do Markets Come From?" American Journal of Sociology, 87: 517-547. 
Williamson O.E. 1975. Markets and Hierarchies: Analysis and Antitrust Implications. New York: Free Press.

Williamson O.E. 1985. Economic Institutions of Capitalism. New York: Free Press.

Williamson O.E. 1991. "Comparative economic organization: Analysis of discrete structural alternatives." Administrative Science Quarterly, 36: 269-296.

Williamson O.E. 1991. "Strategizing, economizing and economic organization." Strategic Management Journal, 12 (Winter Special Issue): 75-94.

Yonay, Yuval. 1998. The Struggle Over the Soul of Economics: Institutionalist and Neoclassical Economists in American Between the Wars. Princeton, NJ: Princeton University Press.

Zelizer, Viviana A. 1983. Morals and Markets: The Development of Life Insurance in the United States. New Brunswick, NJ: Transaction. 